\title{
Sabores docentes: relato reflexivo da experiência de estágio na construção da imagem docente
}

\author{
Teaching flavors: reflective report of the internship experience in the \\ construction of the teaching image
}

\author{
Bruna Linéia Parahyba ${ }^{1}$ \\ Andréa Inês Goldschmidt ${ }^{2}$
}

\section{Resumo}

O artigo tem como objetivo refletir sobre as experiências e atividades desenvolvidas durante o Estágio em Licenciatura em Ciências Biológicas. Este proporciona uma interação direta com a prática docente, aproximando a realidade escolar com o estagiário, o que permite com que a construção docente possa ser estabelecida no decorrer do seu desenvolvimento. É fato que o sistema educacional mostra-se cada vez mais fragilizado, e decorrente disso a desvalorização do professor torna-se algo real. Em meio a isso, existe ainda esperança na profissão docente como meio de transformar a educação, através de uma imagem docente voltada à reflexão e criticidade, tendo como auxílio a escrita para organizar as ações desenvolvidas a fim de transformá-las em ações melhores para o futuro.

Palavras chave: estágio; formação inicial de professores; experiência na docência; reflexões.

\section{Abstract}

The article aims to reflect on the experiences and activities developed during the Internship in Licentiate in Biological Sciences. This provides a direct interaction with the teaching practice, bringing the school reality closer to the trainee, which allows the teacher construction to be established in the course of its development. It is a fact that the educational system is becoming increasingly fragile, and as a result the teacher's devaluation becomes real. In the midst of this, there is still hope in the teaching profession as a means to transform education, through a teaching image focused on reflection and criticism, with the help of writing to organize the actions developed to transform them into better actions for the future.

Keywords: internship; initial teacher training; experience in teaching; reflections.

\footnotetext{
${ }^{1}$ Universidade Federal de Santa Maria | bruna_parahyba@hotmail.com

${ }^{2}$ Universidade Federal de Santa Maria | andreainesgold@gmail.com
} 


\section{Introdução}

O que é ser professor hoje? Ser professor hoje é viver intensamente o seu tempo com consciência e sensibilidade. Não se pode imaginar um futuro para a humanidade sem educadores. Os educadores numa visão emancipadora, não só transformam a informação em conhecimento e em consciência crítica, mas também formam pessoas. Diante dos falsos pregadores da palavra, dos marqueteiros, eles são os verdadeiros "amantes da sabedoria", os filósofos de que nos falava Sócrates. Eles fazem fluir o saber - não o dado, a informação, o puro conhecimento porque constroem sentido para a vida das pessoas e para a humanidade e buscam junto, um mundo mais justo, mais produtivo e mais saudável para todos. Por isso eles são imprescindíveis (GADOTTI, 2003, p. 3).

Iniciar esta introdução com esta epígrafe promove reflexões intensas, principalmente considerando o momento de vivência do estágio - importante a todo docente em formação. Compreender o estágio significa entender-se enquanto professor, o que provoca inúmeras inquietações, entre elas, as decisões tomadas há algum tempo, sobre a escolha profissional.

A profissão do professor e a docência têm atribuído a este período de formação inicial, novas formas de pensar. Assim, é imprescindivel "ver o vento", além de apenas senti-lo, pois o que percebíamos até o momento é o seu agir quando balança as folhas das árvores, quando arrasta e levanta a poeira, e quando este é capaz de mudar as direções, nos mostrando novos caminhos a serem seguidos. Citamos o vento, porque assim como Silva e Goldschmidt (2016) afirmam, os ventos provocam mudanças no percurso do caminho, "sopram e mudam a direção de todo barco que por ventura se encontre sobre as águas da vida" (p. 136). Assim, também os ventos nos trouxeram até este momento!

Neste artigo, queremos trazer Edgar Morin, quando explica que podemos fazer uso tanto do "eu", quanto do "nós", o eu se faz necessário neste artigo. Pois quando utilizamos "nós" estamos nos referindo às discussões, produções coletivas que fazem parte da nossa constituição como pesquisadora e que são compartilhadas também por outras pessoas. São ideias e momentos que dividimos com nossos pares, professores, orientadores, colegas do estágio e referenciais teóricos. Quando utilizamos o "eu", manifestamos a pessoalidade do discurso, em trechos que fazem parte apenas da trajetória do pesquisador estagiário, do momento de formação inicial e de lembranças de vida e que sem dúvida, ecoam e interferem neste caminho (SILVA e GOLDSCHMIDT, 2016).

Desta forma, ao usar desta exclusividade, torno foco deste artigo, as expectativas, sonhos, medos, receios e toda a bagagem de histórias, conhecimentos, aprendizagens que trago comigo no decorrer da minha trajetória e da minha vivência de estágio na docência.

Ainda que o vento tenha proporcionado algumas direções distintas na caminhada, esses novos horizontes apresentaram potenciais e encantaram os olhos e o coração. 0 caminho que opto em trilhar daqui para diante, compreendo não ser fácil, mas de encontro ao coração é o que tem me realizado a cada nova experiência. Participar este momento e dividi-lo com o professor orientador é imprescindível e poder compartilhar com outros futuros professores, provoca reflexões importantes, para pensarmos em uma formação docente mais humanitária. Rodrigues (2009) discute que entre professores orientadores de estágio e os estudantes, dá-se uma interação intensa, na busca de conhecimentos e recursos próprios do trabalho docente, para o qual o estágio se prepara. 
Pimenta e Lima (2004) sinalizam que a função do professor orientador do estágio será, à luz da teoria, refletir com seus alunos sobre as experiências que já trazem e projetar um novo conhecimento que ressignifique suas práticas. Portanto, o professor orientador, com sua maneira própria de ser, pensar, agir e ensinar transforma seu conjunto de complexos saberes em conhecimento efetivamente construído. Faz com que o estagiário não apenas compreenda, mas questione, incorpore e reflita sobre estes ensinamentos de variadas formas (FONSECA, 2003 apud PIMENTA e LIMA, 2004).

Discorrendo sobre esta experiência vivenciada, nos propomos a ponderar sobre a docência e descrever sobre o que realmente importa neste momento: a realização do estágio. O estágio supervisionado curricular é obrigatório aos cursos de licenciatura, de acordo com a Lei de Diretrizes e Bases da Educação Nacional, LDBEN (9394/96), e trata-se de uma porta de entrada de contato efetivo com a prática profissional docente. Santos (2005) afirma que o estágio supervisionando é um espaço de construções significativas no processo de formação de professores e deve ser compreendido como uma oportunidade de formação contínua da prática pedagógica, que estabelece uma ponte de aproximação entre o cotidiano no qual o estagiário irá atuar.

Neste contexto, o estágio é uma ferramenta em prol da formação do professor, com vistas a incluir em cada etapa desta construção do profissional docente, o desenvolvimento de habilidades para lidar com as dificuldades escolares e estar familiarizado com as vantagens e desvantagens que o contexto atual da educação disponibiliza. Ainda, leva em consideração a criticidade e a reflexão sobre cada prática, para que a identidade docente seja estabelecida de forma coesa, focando-se na possiblidade de buscar a melhoria através dessas ações.

Segundo Pimenta e Lima (2005), o estágio tem por propósito promover uma reflexão a partir de uma aproximação e envolvimento intencional com a realidade, pois propõem que esta vivência proporciona o desenvolvimento de:

(...) atividades que possibilitem o conhecimento, a análise, a reflexão do trabalho docente, das ações docentes, nas instituições, de modo a compreendê-las em sua historicidade, identificar seus resultados, os impasses que apresenta as dificuldades. Dessa análise crítica, à luz dos saberes disciplinares, é possível apontar as transformações necessárias no trabalho docente, nas instituiç̃̃es (PIMENTA e LIMA, 2005, p. 20).

Alarcão (2005) já dizia que o ser humano atual "é um Homem que, de certo modo, quer reaprender a pensar" (p. 174). O processo de reflexão, de querer repensar nas práticas dentro da docência torna-se fundamental para o desempenho profissional, já que visa tornar o indivíduo crítico sobre sua ação docente, alterando positivamente o ambiente escolar e a construção do ensino-aprendizagem (FONTANA e FÁVERO, 2013).

Decorrente disso, este artigo consolida a disciplina de Estágio Curricular das Ciências Biológicas no Ensino Médio II, no curso de Licenciatura em Ciências Biológicas pela Universidade Federal de Santa Maria campus Palmeira das Missões. No transcorrer deste artigo faremos um relatado sobre as experiências pessoais e coletivas durante o estágio, bem como uma reflexão sobre "os ventos", escolhas, caminhos e decisões tomadas no decorrer desta formação. 


\title{
Saborear o ato de contar história: entre relatos e rabiscos
}

Analisar-se é aprender a narrar a si mesmo. Parece fácil, mas muitas pessoas não conseguem falar de si, não sabem dizer o que sentem. Para mim não é tão difícil, já que escrever ajuda muito no exercício de exporse. Quem escreve está sempre se delatando, seja de forma direta ou camuflada (MEDEIROS, 2013, p. 128).

Começamos por compreender o verdadeiro sentido do estágio e desta forma, entendemos a necessidade de se perceber e começar a se revelar. Revelar-se é ir encaixando as palavras, criando versos e enfeitando os sentimentos com poesia. Isto não parece ser algo fácil a se desempenhar, mas também não deve causar aversão suficiente a ponto de querer evitar. De contrapartida é notável que o ato de escrever requeira responsabilidade, é necessário fidelidade ao emaranhado de histórias entrelaçadas que a memória guarda. Transformar lembranças em palavras, versos e textos organizados tornase algo complexo de construir.

Neste momento o ato de escrever, de ser capaz de se descrever e de relatar as histórias e experiências, faz com que entremos em um mundo profundo, cheio de emoções guardadas, às vezes até desconhecidas dentro do consciente ou inconsciente. A mente torna-se o centro do mundo, as histórias são o mar, nós e os protagonistas somos os peixes que estão a nadar. Acionar estas memórias, não é algo automático, requer reflexões e organização!

\begin{abstract}
Vivemos em um mar de histórias, e como os peixes que (de acordo com o provérbio) são os últimos a enxergar a água, temos nossas próprias dificuldades em compreender o que significa nadar em histórias. Não que não tenhamos competência em criar nossos relatos narrativos da realidade - longe disso, somos, isso sim, demasiadamente versados. Nosso problema, ao contrário, é tomar consciência do que fazemos facilmente de forma automática (BRUNER, 2001, p. 140).
\end{abstract}

Podemos assim, ilustrar a fonte de onde vem o referencial teórico, como um espaço desorganizado, qual a escrita tem o propósito de organizar. Bruner (1998) apud Prado e Soligo (2007) argumenta que "é muito provável que a forma mais natural e mais imediata de organizar nossas experiências e nossos conhecimentos seja a forma narrativa" (p. 165).

Chaves (2005) discorre que as memórias evocadas revelam como o passado e o presente está intimamente relacionado à constituição do nosso fazer docente e evocá-las nos mostra um caminho fecundo à medida que as reminiscências ensinam-nos a compreender e a transformar o nosso ser.

Ramos et al. (2016) enfatizam que na formação inicial de professores, além de outros aspectos, o autoconhecimento é fundamental, podendo algumas questões serem problematizadas e mediadas por intensas reflexões, como compreender "por que quero ser professor e que tipo de professor eu quero ser?" 


\section{Selecionando sabores: entre lembranças e memórias}

Lembrando a que me proponho trago neste revelar, minhas experiências individuais. Descrevo-me como rabiscos a serem aperfeiçoados pelo caminho, como um escritor que faz um esboço e depois o embeleza com toda a emoção que se pode expressar. Voltar atrás para olhar, refletir, reviver e reescrever torna-se uma ação constante. Assim como pronunciou Cunha (2007) baseado nas leituras de Soares (1991) a "nossa vida é bordada sem conhecimentos prévios do desenho rabiscado e sem conhecimentos por inteiro a peça" (p. 70). E ao ato de voltar para observar, refletir e debruçar sobre estes rabiscos já arranjados pode resultar em possíveis novas percepções daquilo que de início foi ignorado, a fim de que sejam compreendidas todas as partes. É deste modo que defino este momento, as letras magicamente põem-se uma após a outra e quando o ponto final de uma frase é proposta, aí então tudo começa novamente. Assim é o ato de construir um artigo reflexivo.

Chaves (2005) enfatiza que é essencial que, como professores nos conhecermos, para (re)educarmos-nos e estarmos dispostos a nos educarmos permanentemente; e ainda, que esta é a lição que todos devemos aprender, enquanto professores.

Escolho usar da simplicidade para contar das minhas sensações vividas, dos arrepios, dos "frios na barriga" e da experiência que é saborear cada momento. Saborear! Evoco este verbo a fim de tentar transcrever essas percepções vivenciadas até agora, de modo que este fluxo de memórias e as lições que pude sugar dessas experiências sirvam de combustível, qual poderá mostrar e clarear o caminho até a criatividade para então escrever na busca de uma identidade docente!

Falar sobre a escrita através dos sabores é falar do compartilhar dos "alimentos", elementos que fizeram e fazem parte da escrita. Elementos que se agregam e que são geradores e disparadores de memórias, ou mesmo, construtores de outras memórias. (ALBUQUERQUE, SERPA e ARAPIRACA, 2010, p. 55).

Saborear, palavra esta que remete ao sentido do paladar. E neste significado ela fornece diferentes formas de se contar experiências com relação ao mundo. O saborear faz pensar sobre o sentido do gosto, das doçuras e do prazer que é degustar lentamente cada experiência vivida. É claro que nem sempre os sabores foram bons, há divergências constantes de paladares, mas cada momento faz parte do processo de se construir algo, de criar histórias, de crescer e dar forma a nossa identidade docente.

Deixo-me levar pelos devaneios da minha vida, buscando recordar e retirar do fundo dos baús da minha memória, cada detalhe que contribuiu para esta contínua formação na qual estou seguindo trajeto. Sabendo que as conexões aqui realmente existem, sendo a minha mente conectada com o meu coração. A sinapse é contínua e a cada momento estão chegando novas informações. Isto é, enquanto estou a escrever, tentando costurar e organizar com linhas tortas a minha retrospectiva de conhecimentos históricos, também estou a construir mais um pouco da minha própria história. Como Mélich proferiu, expressando este processo como um relato inacabado, que chega ao fim somente com a morte. 
Somos o relato que nós contamos e que nos contam, um relato inacabado, que não se pode terminar. Somos o relato que só finaliza com a morte. A morte é fim do trajeto (...). Porém, enquanto isso, vivemos brincando, narrando (MÉLICH apud PRADO e SOLIGO, 2007, p. 54).

Prado e Soligo (2007) já abordaram certa vez, dizendo que "a história é feita com o tempo, com a experiência do homem, com suas histórias, com suas memórias" (p. 45). E tratando-se do relato do que vivi, mas também do contexto de muitos acadêmicos que estão a passar, ou passaram pelo mesmo processo, tenho a certeza de que alguém externo possa se sentar e assim degustar, digerir ou saborear. Se identificar com textos, com as palavras, versos e poesias expostas aqui, e se necessário até criticar, como nas divergências de sabores e sabendo de que cada indivíduo possui sua própria opinião, às vezes diferente da nossa, me proponho a continuar.

Sou consciente que o temor sobre as críticas dá-se pelo motivo de eu ser o reflexo de outro. E quando cito o outro aqui, refiro-me ao leitor. Temo as críticas justamente porque há esta ligação do meu eu com o externo. Esta reflexão trás a tona à crença de que as minhas experiências podem ganhar voz a outra pessoa, sendo elas o encaixe de ocasiões que o outro viveu. Mota (2007) compreende que o temor pelas críticas durante a escrita dáse por este motivo, de que escrevemos para alguém. Sobre isto, escreve:

Por que sempre tememos as críticas sobre o que escrevemos? Porque existe o outro. Porque o outro é o nosso espelho. Porque a escrita é a ponte que me leva até o outro que não sou eu. Eu, o escritor, oriento minha palavra considerando o meu outro. Esse modo de realizar a escrita a partir do meu leitor é representado pelo espelho onde tento refletir minhas ideias, pensamentos, conceitos, verdades, realidades, tentando encontrar meus tantos outros eus (MOTA, 2007, p. 79 e 80).

Não posso hesitar neste momento e deixar de dizer que a credibilidade do meu ser está na leitura que o outro, externo faz. Bakhtin (1992, p. 113) supõe que a "orientação da palavra em função do interlocutor", ou seja, do leitor "tem uma importância muito grande". Isto ocorre porque a palavra "comporta duas faces". Pois "ela é determinada tanto pelo fato de que procede de alguém, como pelo fato que se dirige para alguém". Ou seja:

Toda a palavra serve de expressão a um em relação ao outro, através da palavra, defino-me em relação ao outro, isto é, uma última análise, em relação à coletividade. A palavra é uma espécie de ponte de lançamento entre mim e os outros. Se ela se apoia sobre mim numa extremidade, na outra se apoia sobre o meu interlocutor (BAKHTIN, 1992, p. 113).

É por este motivo que sempre existirá esta ligação, sendo eu o espelho que reflete as minhas ideias e procura os outros "eus" para se identificar. Lembrando que os reflexos das escolhas que me trouxeram até este momento, podem ser os mesmos reflexos que estão a levar outras pessoas - a quem sabe - ao mesmo lugar, e então o meu "olhar recebe um outro reflexo" (WAECHAUER, 2001, p. 190); ou seja, um reflexo externo, de quem está lendo.

Dos prazeres do que é escrever, ainda cito que a escrita abre um novo mundo dentro das minhas próprias possibilidades. Pois é preciso pensar sobre quais lembranças escrever, como organizá-las e quais palavras utilizar para descrever de forma que o leitor entenda. 
Para isto, o trabalho de escrever é muito mais do que combinar palavras bonitas e soltá-las no papel de forma que as mesmas se encaixem. Descobri que a escrita vai além, e exige um pensamento voltado à reflexão.

Compreendo a reflexão de dois modos, primeiramente é necessário refletir sobre a importância de selecionar lembranças significativas que fizeram com que eu chegasse exatamente até aqui - ao ato de escrever e narrar as minhas experiências. O outro sentido da reflexão é a que encontro no decorrer da experiência com a docência. Que nada mais é do que a reflexão, das minhas ações, das práticas que desenvolvi durante a regência em uma turma de alunos decorrente do período de estágio.

Faço das memórias e da reflexão, o fermento para o crescimento desta narrativa, o combustível já mencionado para auxiliar na criatividade quanto à literatura deste relato. E como Rosa (2007) já articulou "escrever é um processo complexo. Entre o desejo e o ato da escrita, há um exercício trabalhoso, que envolve acumular informações e selecioná-las" (p. 255). Este é o caminho que está sobre mim, o que escolhi seguir! Ser capaz de selecionar informações, refletindo sobre elas. Refletir sobre o que escrever também é algo importante e vai além do que se pode imaginar, pois a reflexão é o que nos mantem em constante formação e reformulação de nossa identidade.

Explicado o que a escrita representa para mim até este ponto, debruço-me nas páginas em branco, a preencher meus anseios, apreensões, expectativas, experiências, vivências e toda a história que construí até aqui, e que de certa forma me dirigiram. Seguro com as minhas mãos, de forma figurada a escrita e a reflexão para me auxiliar nesta construção dos meus relatos históricos e recorro algumas vezes à metáfora. Segundo O'Connor e Seymour (1995) apud Goldschmidt (2016) "Uma metáfora contada de maneira clara e simples distrai a mente consciente e ativa a procura inconsciente de significados e recursos" (p. 26). Escrever em forma de metáfora favorece a revelação de elementos ocultos que somente o inconsciente pode acionar e então se torna um caminho para a reflexão (GOLDSCHMIDT, 2016).

E nos embalos que a vida me coloca, deparo-me agora no ato de selecionar, o que realmente vale a pena citar no papel. Para acionar estas memórias, entro em profunda conexão com o meu passado, a fim de resgatar algo significativo que me levou a estar aqui hoje. Estou despindo da minha identidade para escrever este mar de histórias qual já vivi. 0 presente qual vivo são reflexos das passagens anteriores e cito Soares (2001):

Exatamente assim é que me sinto: com as mãos atadas pelo que hoje sou, condicionada pelo meu presente, é que procuro narrar um passado que re-faço, re-construo, re-penso com as imagens e ideias de hoje. (...) obedecer a critério do presente: escolho aquilo que tenha relações com o sistema de referências que me dirige hoje. A (re) construção do meu passado é seletiva: faço-a a partir do presente, pois é este que me aponta o que é importante e o que não é; não descrevo, pois; interpreto (SOARES, 2001, p. 27).

Sinto-me como se estivesse sentada em uma varanda, com um entulho de caixas, abrindo-as uma após a outra, na tentativa de encontrar um ponto de luz para o que colidiu na escolha que seguisse nesta jornada. O primeiro ponto de luz em minhas memórias não poderia ser diferente, nem mesmo me surpreende, quando me deparo a este instante da minha história, que já fez e faz-me querer renascer para a vida novamente: os sonhos. 
Santos (2010, p. 17) afirma que "sonhar faz parte da vida, dignifica o homem e alivia por completo a sua alma".

Ah! Os sonhos! Quão maravilhoso eles são para mim, pois eles me formam! Caracterizam-me! Sou a junção de muitos sonhos. Minha trajetória acadêmica começou pela escolha de submeter-me ao vestibular para o curso de Ciências Biológicas em licenciatura na Universidade Federal de Santa Maria Campus de Palmeira das Missões. A verdade é que de início, escolhi este curso pelo desejo de tornar-me bióloga. De imediato junto à escolha do curso, veio a dúvida sobre a licenciatura, se iria gostar da docência, se seria um peso a se carregar para se formar ou se deveria desistir do curso e procurar o bacharelado. Interligado a estas dúvidas, surgiram os medos. Mas o sonho de cursar biologia era maior do que os medos de me tornar professora. E entre os anseios, um deles estava voltado ao julgamento prévio de minhas habilidades quando me imaginava ser professora e da infelicidade de me deparar com o descaso com a educação e seus protagonistas no nosso país.

Assim, nesta intrigante dúvida, ecoava a voz de uma menina que, ainda jovem e com poucas certezas na vida, ignorava as influências dos ventos agitados e inesperados sobre suas escolhas (SILVA e GOLDSCHMIDT 2016, p. 136).

Percebo que os ventos me levaram a esta direção, onde no meio do caminho, depareime com a docência. No processo de realização de um sonho, encontrei outro! Confesso, em meio a minha emoção que me descobrir na docência foi surpreendente, e no decorrer desta trajetória o foco mudou. Não que eu tenha deixado de amar a biologia e tudo o que a cerca, mas jamais imaginei que a biologia poderia me oferecer a oportunidade de me apaixonar novamente e desta vez pela licenciatura.

Quando sonhei em entrar na universidade mal imaginei que primeiramente mudaria meu foco, meu sonho encontraria outros caminhos e que para realizá-lo teria que ultrapassar obstáculos para chegar ao objetivo de vestir a toga e adquirir o mérito de ser licenciada em Ciências Biológicas. Para isto foi necessário vestir-me da armadura da ousadia e realmente ultrapassar alguns limites de timidez, nervosismo diante de alunos em fase da adolescência.

No decorrer do curso me deparei com várias disciplinas que deram apoio para a realização do ser professor. Igualmente o estágio possui esta característica de fazer a ligação entre as teorias abordadas durante o curso, consolidando e se complementando com as práticas desenvolvidas no decorrer do estágio. Sobre isso, posso citar Santos (2005, s/p) qual argumenta dizendo que: "o Estágio Supervisionado Curricular, juntamente com as disciplinas teóricas desenvolvidas na licenciatura, é um espaço de construções significativas no processo de formação de professores, contribuindo com o fazer profissional do futuro professor". Scalabrin e Molinari (2013) afirmam ainda que "o estágio é uma prática de aprendizado por meio do exercício de funções referentes à profissão será exercida no futuro e que adiciona conhecimentos práticos aos teóricos aprendidos nos cursos" (p.2).

Senti-me de olhos vendados, sem compreender qual o rumo que estava tomando, por me preocupar com minhas limitações, falta de experiência e na imaturidade que tinha no início da graduação. Ainda, por não conseguir ao menos enxergar o que os estágios poderiam me proporcionar, muitas vezes me peguei pensando em: Como seria lecionar? Como eu poderia ser uma boa professora? Como faria isso? Será que iria gostar? 
Alguns semestres se passaram, e quando menos esperei o que estava diante de mim eram as primeiras experiências na docência com a realização dos primeiros momentos de estágio - no ensino fundamental. Estes primeiros contatos com os alunos em sala de aula deram-me a oportunidade de conhecer a vivência enquanto professor na sala de aula, e a perspectiva dos desafios enfrentados diariamente e de como foi difícil de imediato vencer os medos.

Foi durante os estágios no ensino fundamental que a paixão pela docência floresceu. E desta parte lembro-me com nitidez das vezes que sai sorrindo após a regência. Somente os estágios poderiam mostrar-me o verdadeiro valor de lecionar. O estágio foi e é uma via fundamental na formação da imagem docente. Foi de extrema importância, pois faz as "vendas dos olhos" caírem e revelar o desejo em ser professora. O estágio possibilitou os meus primeiros contatos com a escola, com os alunos, com as ações de ensino e aprendizagem. Além disso, o estágio fez a ligação das extremidades dentre a teoria e a prática. Foi possível perceber a importância de fazer um planejamento de ensino para seguir uma ordem cronológica durante as aulas, de levar diferentes estratégias didáticas para deixar o ensino mais dinâmico e atrativo.

Torno a mencionar os ventos das minhas escolhas, pois ao escolher biologia e o curso nesta universidade, escolhi mesmo inconscientemente a licenciatura. Não há como deixar de mencionar que as disciplinas de estágio, até primeiro critério eram apenas para concluir uma matriz curricular. Por isso destaco a importância do estágio, por revelar a beleza em ser professora.

Para corroborar com o que escrevi anteriormente faço menção nas palavras de Scalabrin e Molinari (2013) a importância do estágio ser prático, e de como a partir do estágio percebi a oportunidade de aprender mais sobre a profissão que hoje escolhi desempenhar.

\begin{abstract}
Além disso, o aprendizado é muito mais eficiente quando é obtido através da experiência; na prática o conhecimento é assimilado com muito mais eficácia, tanto é que se torna muito mais comum ao estagiário lembrar-se de atividades durante o percurso do seu estágio do que das atividades que realizou em sala de aula enquanto aluno. Na efetiva prática de sala de aula o estagiário tem a possibilidade de entender vários conceitos que Ihe foram ensinados apenas na teoria. Por isso, o estudante deve perceber no estágio uma oportunidade única e realizá-lo com determinação, comprometimento e responsabilidade. Seria apenas um desgaste caso não houvesse interesse em aprender e preparar-se para a futura profissão (SCALABRIN e MOLINARI, 20013, p. 3).
\end{abstract}

É por este motivo que chego ao Estágio Supervisionado do Ensino Médio II muito aliviada. Sabendo que escolhi esta profissão e que não estou realizando esta tarefa apenas para concluir a graduação. Mas vejo a janela aberta para aprender mais e para construir esta imagem docente, qual não tinha antes. Deixo meus medos de lado para enfrentar as minhas limitações, como a timidez, insegurança, a falta de conhecimento e a minha tão pouca preparação, e me encorajo a entrar nesta busca ousada de unir a paixão desadormecida pela educação, com a paixão ardente pela biologia e tudo que a envolve.

Dentre tantos aprendizados com a realização do estágio adquiri conhecimentos do campo de trabalho docente, bem como conhecimentos pedagógicos, administrativos, de organização e funcionamento da escolar, entre outros aspectos. Domingues e Gusso (2005) comentam que é de grande relevância o momento de estágio "uma vez que nele são 
expressos mais do que práticas ou técnicas de ensino, mas a própria concepção do futuro professor, em relação ao conhecimento, ao homem e a sociedade da qual está inserido e é parte" (p. 515).

Além disso, o estágio proporciona e proporcionou a mim a práxis junto à reflexão das ações tomadas dentro da sala de aula, dentro da escola e em tudo que envolvia ações decorrentes da docência. Sobre isso Barreiro e Gebran (2006) argumentam que "o estágio (...) pode se construir no lócus de reflexão e formação da identidade ao propiciar embates no decorrer das ações vivenciadas pelos alunos, desenvolvidas numa perspectiva reflexiva e crítica, desde que efetivado com essa finalidade" (p. 20).

E para, além disso, Silva e Goldschmidt (2016) denunciam totalmente os meus sentimentos em relação a este momento de estágio em minha vida acadêmica.

Sendo um período de crescimento, construção e desconstrução, o Estágio afetou tanto minha vida pessoal como também minha formação como futura professora. Foi um período de retorno, de forma reflexiva, àqueles momentos de fuga da docência que havia no meu passado. Percebo então semelhanças e diferenças entre o que pensava e penso hoje; a existência de medos que passaram e outros que se fortaleceram; medito e investigo sobre o que me afastava e afasta da docência, mas também sobre o que me atrai a estes caminhos e faz com que eu permaneça aqui. Posso meditar sobre conflitos possivelmente presentes na vida de graduandos que um dia decidiram trilhar o mesmo caminho que eu, e se depararam com uma graduação e com uma realidade escolar saturada de problemas e de sonhos (SILVA e GOLDSCHMIDT, 2016, p. 138).

\section{Dos sabores da docência: existe receita para ser professora?}

Quando comecei a refletir sobre o que significava ser professora, dos processos desta construção docente, imaginava e comparava esta profissão a de uma confeiteira. Isto porque uma confeiteira, ao colocar em prática uma receita de bolo, retira das prateleiras ingredientes certos. Escolhe com êxito os utensílios necessários para auxiliar na preparação e magicamente com as medidas certas, acrescenta uma dose disso, algumas colheres daquilo, outras várias xícaras de outros ingredientes e uma pitada de fermento. Com a mistura pronta e com todo o cuidado, esta é despejada em um recipiente e submetida ao calor, para que após o período de preparo possa ser saboreado com exatidão.

Definitivamente não é com farinha, chocolate e modos de preparar um bolo qual estou a tentar descrever. Mas esta trajetória trouxe-me expectativas como essas, pois ao comparar a docência com uma confeitaria, imaginava que a licenciatura era realmente a escolha de uma receita e ao seguir cada passo e detalhe da mesma, ao final teria uma experiência boa, saborosa e eficaz! A receita dentro da docência seguiria pelo uso de utensílios-materiais, como por exemplo, quadro de escrever e canetão ou projetor multimídia, os ingredientes seriam os conhecimentos a serem construídos de determinado conteúdo e o modo de preparar a receita, estaria relacionado às variadas estratégias didáticas para abordar a aula. De forma, exata, ao final, a mistura estaria certa: a construção do conhecimento, o ensino aprendizagem.

Quando finalmente comecei a ter os primeiros contatos com a sala de aula, percebi a realidade que se apresentava: a docência não nos dá nada pronto! Não há uma receita, a fim de que se seguirmos corretamente no final não haverá erros. A prática é muito mais 
desafiadora, requer ousadia, requer riscos, requer criatividade, requer afetividade. Exige uma transformação no pensamento!

Santana (2005) afirma que nesta busca, recorrer a literatura especializada sempre configura uma alternativa; porém, tal ação deve ser conjugada com reflexões onde aqueles que efetivam o fazer educacional, precisam reavaliar os próprios limites, as concepções prévias e estudar continuamente. Buscar efetivar algo diferenciado sem esta compreensão pode resultar em ações vazias.

\section{Novos sabores: o ato de conhecer a escola}

Uma das etapas de grande importância durante o estágio é o momento de conhecer a escola. Este momento é imprescindível para os estagiários, já que o conhecer aqui não se trata somente de uma leitura das estruturas físicas. Vai além, conhecer eleva seu significado à ação de vivenciar a realidade que a escola oferece. Silva e Goldschmidt (2016) agregam que durante esta fase "o ato de conhecer não é somente o estar num lugar físico, mas vivenciá-lo; é sentir seu gosto, sua textura, suas cores e formas" (p.141).

Conhecer a escola mais de perto significa colocar uma lente de aumento na dinâmica das relações e interações que constituem seu dia-a-dia, apreendendo as forças que a impulsionam ou que a retêm, identificando as estruturas de poder e os modos de organização do trabalho escolar, analisando a dinâmica de cada sujeito nesse complexo internacional (ANDRÉ, 1995, p. 111).

Este momento caracteriza-se pelo ato de desvendar aquilo que o dia a dia da escola esconde, abrem-nos os olhos para enxergar a escola em sua totalidade, com suas formas físicas e corpóreas; dá-nos a oportunidade de experimentar e saborear as vivências dentro da aprendizagem e da boniteza que é ensinar.

Esta concepção que a palavra "conhecer" recebe durante este processo, tanto na vivência da realidade escolar, quanto na sua estrutura física, traz atrelado o significado da palavra "cognose". Palavra esta, que segundo Rezende (2012) apud Silva e Goldschmidt (2016), vem do conceito inicial de cognição, que tem origem nas escritas de Platão e Aristóteles e foi atribuída ao significado de conhecer. O sufixo "ose" advindo do grego fazse necessário pelo efeito de ação, dado ao processo de vivenciar para conhecer. Além de dar a este termo $\mathrm{o}$ ato de conhecer, o autor, ainda considera vários aspectos complementares a este processo, tais como a atenção, a percepção, a memória, o juízo, o raciocínio, o pensamento e a linguagem.

Os processos de conhecimento da escola, referido como cognose, ocorrem pelas experiências que temos durante o estágio, onde são oportunizados os momentos de contato direto com a escola parceira. A escola que disponibiliza seu espaço físico, seus alunos e seu tempo, é chamada de escola campo ou escola parceira. É ela que proporcionará ao aluno estagiário o local de ação para o desempenho das atividades decorrentes. Silva (2006) argumenta que:

A Escola-Campo se constitui, então, no espaço/tempo que oferece ao estagiário a oportunidade de conhecer o funcionamento da escola como um todo (...) estar na Escola-Campo, seja em processo de observação ou de regência, permite ao futuro professor presenciar as práticas educativas que envolvem todo o trabalho na sala de aula, relação professor/aluno, 
processo de aprendizagem, metodologia, enfim, todos os elementos que compõem as práticas educativas do professor (SILVA, 2006, p. 42).

A realização deste estágio ocorreu nas dependências da escola campo Colégio Estadual Três Mártires, localizada no município de Palmeira das Missões. Esta instituição de ensino foi fundada em 1951 e atende nos três turnos do dia com educação infantil, ensino fundamental, ensino médio e cursos técnicos sendo estes cursos de Informática, Contabilidade, Administração e Saúde Bucal.

É importante durante o estágio, além de conhecer a escola campo, compreender as concepções que a determinam. Para isto, imprescindível conhecer o Projeto Político Pedagógico (PPP) da escola. Libâneo (2013) explica que o PPP:

(...) é um guia para a ação, prevê, dá uma direção política e pedagógica para o trabalho escolar, formula metas, institui procedimentos e instrumentos de ação. A gestão põe em prática o processo organizacional para atender ao projeto, de modo que este é um instrumento de gestão (LIBÂNEO, 2013, p.126-127).

Diógenes e Carneiro (2005) também ponderam sobre a importância deste documento nas escolas.

(...) O PPP é de vital relevância para nossas escolas, pois, deverá refletir a sua visão de mundo, de sociedade, de cidadão atuante na sociedade. É importante enfatizar que nele deve estar clara a tendência de como se trabalha o conhecimento, bem como o viés político da instituição escolar que o elaborou. Por isso, o projeto pedagógico é uma proposta de educação cujo objetivo é desenhar o mapa condutor da educação que sonhamos, caracterizando-se como um instrumento de mediação na relação teoria-prática (DIÓGENES e CARNEIRO 2005, p. 139).

Este documento tem como objetivo guiar profissionais da escola, alunos e familiares, evidenciando planos de ação, características da escola e também metas a serem conquistadas em conjunto com a comunidade. O PPP do Colégio Estadual Três Mártires está baseado em uma filosofia que "tem em vista a construção do conhecimento e o desenvolvimento do aluno como cidadão consciente, crítico, participativo, capaz de interferir na sociedade em que vive" (PPP, 2011, p. 6). Neste contexto, de acordo com a comunidade escolar, esta instituição de ensino defende e assume o papel da escola, como um compromisso social com a formação do aluno-cidadão e com uma educação de qualidade.

Veiga (2002) explica o porquê de um PPP possuir a abordagem voltada à cidadania, uma vez que é esta característica que disponibiliza uma aprendizagem que estimula esses aspectos em seus alunos. Nas palavras da autora:

(...) todo projeto pedagógico da escola é, também, um projeto político por estar intimamente articulado ao compromisso sociopolítico com os interesses reais e coletivos da população majoritária. É político, no sentido de compromisso com a formação do cidadão para um tipo de sociedade (VEIGA, 2002, p.12).

O documento desta escola parceira, ainda discorre sobre os objetivos gerais que a instituição de ensino propõe aos seus alunos, apresentando: a disposição da escola quanto às condições para a realização do processo de ensino aprendizagem; utilizar da 
experimentação e observação para desenvolver no aluno o raciocínio lógico e a competência de identificar, avaliar para melhor resolver problemas; possibilitar ao aluno uma comunicação com a sociedade de forma eficiente, respeitando a opinião e o conhecimento produzido pelo outro, destacando a forma do diálogo como importante mediador para o processo coletivo nas tomadas de decisões; e, por fim, proporcionar ao aluno uma compreensão individual baseado nas características de um sujeito histórico, concreto, autônimo, participativo e crítico, para o desenvolvimento de competências para ação e intervenção na sociedade, expressando plenamente a cidadania e democracia.

Além disso, a escola acredita:

(...) que a educação tem o papel de contribuir para que o ser humano venha descobrir suas próprias possibilidades, centrada nos interesses emancipatórios do aluno que deve ser capaz de, coletivamente, criar suas próprias formas de organização sendo sujeito de sua história, construtor do seu conhecimento e da sociedade em que vive. O conhecimento é reconstruído através do processo de interação entre professor, aluno e o próprio objeto do conhecimento. Para isso se deve levar em consideração as potencialidades dos alunos e os níveis de desenvolvimento para que as novas informações, competências, habilidades e atitudes possam ser aprendidas pelos mesmos e estabelecidas novas relações, ressignificando o próprio conhecimento. Sabe-se que esse não é algo pronto e acabado, mas faz parte de um processo que deve ser contextualizado a partir dos saberes elaborados e sistematizados ao longo da história e do cotidiano de cada educando (PPP, 2011, p. 9).

Por fim, o PPP da escola, sinaliza também para o dever do professor dentro do colégio: (...) o professor deve dominar o conhecimento de sua disciplina para levar o aluno a estabelecer relações entre esse conhecimento e a solução dos problemas que lhe são propostos, isto é, construir competências e habilidades. Assim o professor não deve se ater apenas às atividades do livro didático, deve ser um problematizador, envolver os alunos em suas aprendizagens, em seus trabalhos, além de oportunizar atividades em grupo em que cada integrante deve saber com clareza como atuar de modo cooperativo (PPP, 2011, p. 9).

Propusemos citar este trecho a fim de destacar o caminho que o professor deve seguir dentro da escola, levando em consideração que para além da regência durante o estágio, devemos reconhecer nosso papel enquanto professores em formação inicial, para construirmos nossa identidade docente.

\section{Docência e suas divergências de sabores}

Guardamos este momento para destacar algumas concepções para nos tornarmos bons profissionais na educação. Não queremos dizer com isto, que exista um modelo certo a ser seguido! Nem que há um errado, nem tampouco que exista um melhor que o outro! Quando refletimos sobre isto, desejamos inferir que precisamos estabelecer o tipo de professor que queremos ser, podendo ser este tradicional, ou mais reflexivo, por exemplo. Temos que definir nossas concepções, pois elas determinam o modo como vamos conduzir as aulas, como trataremos nossos alunos, estabelecem nossa identidade docente, os valores 
que construímos e o quanto as experiências que tivemos durante a nossa vida, determinam quem somos e como professores nos tornamos. Tardif (2002) corrobora que o saber dos professores está relacionado a sua própria pessoa e sua identidade, suas experiência de vida e sua história profissional; ainda está relacionado as suas relações com os alunos e com outros atores escolares.

Compreendendo a importância desta história pessoal, e o quanto a identidade docente se constrói também durante o estágio, remeto-me como estagiária, a um episódio pessoal durante este estágio e opto em relatá-lo aqui. Há alguns dias atrás, encontrei meus alunos os mesmos quais desenvolvi o estágio de regência - num contexto fora de sala de aula. A docência havia acabado e aquele momento seria para despedir-me do estágio, dos alunos e da professora regente. O mais assustador foi este momento ter guardado tanta singularidade para minha história. Isto porque a abordagem dos alunos ao chegar ao local de encontro, tornou-se calorosa e animadora, quando os mesmos me cumprimentaram dizendo: Oi professora Bruna!

Professora? Sou mesmo professora? A verdade é que somente ao término deste, percebi que é esta a imagem que meus alunos reconhecem em mim. E esta imagem, agora se torna algo singular, de uma emoção quase palpável. Percebi que nossa imagem docente também se constrói com o olhar do outro.

\section{Sala de aula: dos sabores que provei}

Anteriormente, descrevi algumas experiências imaturas que tinha no início da graduação, quando escrevi sobre as minhas ilusões e esperanças de encontrar na docência uma receita a seguir. Porém, todas minhas reflexões me levaram a compreender que não há receitas a serem seguidas. Há sim, estratégias que fazem do professor alguém melhor, mais capacitado e transformador de sua realidade. Compreendo também que isto não se faz sem a reflexão e a discussão aos pares! É indispensável lembrar Nóvoa (2003, p. 25) quando sinaliza que a formação inicial do professor é coletiva, justo porque "ninguém é professor sozinho, isolado. A formação exige partilhar. A atividade docente necessita de dispositivos de acompanhamento".

Chego a este ponto desse artigo, perguntando-me, como no meio de tantos problemas no sistema educacional e tantas desvantagens, a docência revela em mim tamanho desejo de licenciar? E para além, que tipo de professora vou ser? Uma vez que minhas escolhas já estão feitas, e este é o caminho qual desejo trilhar.

É fato de que quando falamos em escola, de imediato retiramos das nossas memórias o paradigma ao qual estamos passando atualmente. $O$ que vivenciamos hoje são momentos difíceis na educação, consequências de vários fatores envolvidos como a crise econômica, a falta de interesse, apatia ou até mesmo a violência. Goes (2014) afirma ser necessário estar em alerta para todos os problemas envolvidos no sistema educacional da modernidade, sendo estes o descaso do governo, o desinteresse dos alunos e das famílias, as péssimas condições de trabalho, entre tantas outras situações precárias que a escola se encontra.

Não há como não olhar para os acontecimentos que envolvem a escolarização e perceber, que aos poucos a educação e a valorização do professor têm decaído. O contexto escolar torna-se um paradoxo! Pois de um lado temos aumento nos índices de acesso à educação básica e ao ensino superior, sistemas ampliados de bolsas para entrar na 
universidade, etc., e do outro, um conjunto de situações preocupantes, arrastadas pelas contradições que põem obstáculos ao ato da escolarização (FÁVERO; TONIETO e ROMAN, 2013, p. 278).

O envolvimento do professor nesses processos tornou-lhe um dos principais protagonistas, na expectativa de que alguém possa fazer alguma coisa para desafogar a educação que sofre tantos naufrágios. Segundo Goes (2014) existe uma esperança na educação como única forma de mudar o mundo, de contra partida se enxerga também o campo educacional como algo que está completamente arruinado. Mas o autor ainda acredita que está no professor a responsabilidade de transformar a realidade da educação.

Fávero, Tonieto e Roman (2013) enunciam que são os professores os principais protagonistas e que "em função disso é necessário (re)pensar e (re)definir as características da nova identidade da escola e por consequência o perfil dos seus principais protagonistas, os professores" (p. 278 e 279). Libâneo (2013) em suas palavras argumenta a questão dos professores precisarem estar presente nesta constante transformação, pois: "não há reforma educacional, não há proposta pedagógica sem professores, já que são os professores mais diretamente envolvidos com o processo e resultados da aprendizagem escolar" (p. 7).

Tendo em vista o professor, como principal protagonista da tão sonhada revolução na educação, está o fato de refletir sobre este papel, pois se é o professor o principal responsável para estabelecer mudanças no contexto da educação, qual é então a identidade deste professor? Qual é o tipo de professor que faz a mudança acontecer? Qual é a receita a ser seguida?

Silva e Goldschmidt (2016) expõem que "o sonho e o desejo de mudança são essenciais e fazem parte do processo de transformação" (p. 154) e Gadotti (2003) concomitante a isto, corrobora pronunciando que "se o sonho puder ser sonhado por muitos deixará de ser um sonho e se tornará realidade" (p. 2).

Ao me deparar diante disso, lembro-me do início do curso, quando o meu objetivo nem era seguir com a docência e infelizmente esta é a situação de vários graduados que cursam licenciaturas e ao final não irão seguir por este caminho.

Muitos revelam desinteresse em seguir a carreira do magistério, mesmo estando num curso de formação de professores. Pesam muito nessa decisão as condições concretas do exercício da profissão. Preparam-se para ser professor e irão exercer outra profissão (GADOTTI, 2003, p.2).

Não há como julgar as pessoas pelas suas escolhas. Somente posso defender a minha escolha, de estar aqui, e ainda sonhar e desejar que a educação tome rumos melhores. Tentando buscar uma resposta para as minhas próprias escolhas, deparo-me com um trecho do livro Boniteza de um sonho: ensinar e aprender com sentido, do autor Moacir Gadotti, pois ao ler este trecho me identifico de imediato:

Por isso continuo me perguntando: "Por que sou professor?" É uma pergunta que ouço com freqüência também entre meus pares. A resposta talvez possa ser encontrada numa mensagem deixada por um prisioneiro de campo de concentração nazista na qual, depois de viver todos os horrores da Guerra -"crianças envenenadas por médicos diplomados; recém-nascidos mortos por enfermeiras treinadas; mulheres e bebês fuzilados e queimados por graduados de colégios e universidades"- ele pede aos professores que "ajudem seus alunos a tornarem-se humanos", simplesmente humanos. E termina: "ler, escrever e aritmética só são importantes para fazer nossas crianças mais humanas". Talvez esteja aí a 
chave para entender a crise que vivemos: perdemos o sentido do que fazemos, lutamos por salário e melhores condições de trabalho sem esclarecer a sociedade sobre a finalidade de nossa profissão, sem justificar porque estamos lutando (GADOTTI, 2003, p. 02).

Foi quando li e refleti sobre este trecho do livro, que encontrei a respostas para continuar a trilhar neste desejo de ser professora e melhorar a educação com esta profissão. Em meio a leituras e reflexões sobre a educação compreendi que a mudança está no professor, assumir esta responsabilidade não é necessariamente um cargo para mim, mas trata-se de mudar o contexto de algum aluno, na esperança de que o meu entusiasmo dentro da escola o contagie.

Tardif e Lessard (2009) alegam ser a docência "(...) uma forma particular de trabalho sobre o humano, ou seja, uma atividade em que o trabalhador se dedica ao "objeto" de trabalho, que é justamente outro ser humano, no modo fundamental da interação humana" (p. 8). A profissão docente tem como objeto de trabalho o próprio ser humano. Os autores ainda destacam que trabalhar continuamente com outros seres humanos, requer compreensão da parte do docente de que as pessoas não são somente ferramentas ou o alvo do trabalho, mas são considerados como matéria-prima para o processo do trabalho de forma recíproca (p. 20).

Neste sentido acredito ser a docência uma profissão coletiva em que o trabalho caracteriza-se pela interação do ser humano como objeto de trabalho, mas também como sujeito, de forma que o professor compreenda a pessoa em sua totalidade e não apenas veja o aluno como mero receptor de conhecimentos. Sobre isso, Tardif e Lessard (2009) ainda destacam:

Ora a educação repousa basicamente sobre interações cotidianas entre professores e alunos. Sem essas interações a escola não é nada que uma imensa concha vazia. Mas essas interações não acontecem de qualquer forma: ao contrário, elas formam raízes e se estruturam no âmbito do processo de trabalho escolar e, do trabalho dos professores sobre e com os alunos (TARDIF e LESSARD, 2009, p. 23).

É justamente por acontecer esta relação professor e aluno, de ser humano para ser humano, que a docência torna-se um trabalho de maior responsabilidade para o professor. Por isso a relevância em refletir sobre as práticas, ações e atitudes.

Quando compreendo o verdadeiro valor do professor, quando entendo que esta profissão tem muito mais a dar ao mundo e melhorá-lo, deixo um pouco de lado, a preocupação inicial do sonho de ser professora estar colidindo com o sistema educacional falido. Me "visto" com ousadia e coragem, a fim de que de alguma maneira, possa interferir na vida dos meus alunos, de forma que os mesmos procurem se tornarem alguém com atitudes melhores, reflexivos e críticos. 


\section{Considerações finais}

Chegar a este momento é sinal de que muitas transformações de pensamento ocorreram em mim, como uma borboleta que sai do seu casulo após sofrer a metamorfose. Imprescindível é deixar de mencionar sobre a ilusão de que ao trilhar este caminho encontraria uma receita a ser seguida para me tornar professora. A verdade é que existe muito mais simplicidade e menor complexidade no preparo de um bolo do que no preparo para encarar a docência. A docência não nos dá nada pronto e é preciso se submeter ao calor das experiências, com ousadia e sem medo de correr riscos, para que ocorram transformações de pensamento e atitudes, que visem o melhor, no processo de construção de imagem profissional na docência.

Mesmo que a docência não possua receitas prontas, acreditamos ser necessário o uso do fermento, tanto no bolo, quanto nesta experiência de preparação de imagem docente. No processo biológico o fermento é utilizado para fazer o bolo crescer. No decorrer desta trajetória, a reflexão das ações e atitudes frente à docência, ao ensino e aprendizagem, é o fermento utilizado para esta formação, este crescimento da nossa imagem como professora.

No início deste processo, descrevi-me como rabiscos a serem aperfeiçoados pelo caminho, ao chegar a este momento percebo que ainda tenho muito de rabisco e que preciso de muito aperfeiçoamento para ganhar formas mais arranjadas neste processo de construir a imagem docente. Nesta caminhada há muito para servir como material a reflexão, há muita a se descobrir, muito a se aprender e muito a transformar. Devemos seguir procurando (re)inventando-nos (re)criando-nos e (re)construindo-nos constantemente, na tentativa de procurar melhorar sempre e desempenhando com amor aquilo que faz sentido neste momento: a docência.

\section{Referencias}

ALARCÃO, I. Ser professor reflexivo. In: ALARCÃO, I. (org.). Formação reflexiva de professores: estratégias de supervisão. Vol. 1, Porto: Porto Editora, 2005.

AlBUQUeRQue, A. P. T; SeRPA, L. F. S. P; ARAPIRACA, M. A. Formação do educador: reflexões e práticas de sabores, saberes e memórias. In: SOUZA, E. C. (org.) Memoriais: literatura e praticas culturais de leitura. Salvador: Edufba, 2010.

ANDRÉ, M. E. D. A. A contribuição da pesquisa etnográfica para a construção do saber didático. In: OLIVEIRA, M. R. N. S. (org.). Didática: Ruptura, compromisso e pesquisa. $2^{a}$ ed., Campinas: Papirus, 1995.

BAKHTIN, M. Estética da criação verbal. São Paulo: Martins Fontes, 1992.

BARREIRO, I. M. F; GEBRAN, R. A. Prática de ensino: elemento articulador da formação do professor. In: BARREIRO, I.M. F; GEBRAN, R. A. Prática de ensino e estágio supervisionado na formação de professores. São Paulo: Avercamp, 2006. Disponível em: <http://www.fcc.org.br/pesquisa/publicacoes/cp/arquivos/649.pdf> Acesso em: 19 nov. 2016

BRASIL. Lei no 9.394, de 20 de dezembro de 1996. Lei de Diretrizes e Bases da Educação Nacional - LDB. Diário Oficial da União, Brasília, DF, 02 dez. 2016. 
Disponível em: <http://www.planalto.gov.br/ccivil_03/LEIS/L9394.htm>. Acesso em: 02 de dez. 2016.

BRUNER, J. A cultura da educação. Porto Alegre: Artmed, 2001.

CHAVES, S. N. Memórias de formação: reminiscências de formadores de professores sobre suas maneiras de ver e de se na docência. Amazônia Revista de Educação em Ciências e Matemática, v.1 n-1, jul./dez, 2004, v. 1, n-2 - jan./jun. 2005. p. 87-92.

CUNHA, R. B. As memórias nos clássicos e nossas clássicas memórias. In: PRADO, G. V. T; SOLIGO. R. (org.). Porque escrever é fazer história: revelações, subversões e superações. Campinas, SP: Editora Alínea, 2007.

DIÓGENES, E. CARNEIRO, M. J. A gestão participativa e o projeto político-pedagógico: Um exercício de cidadania. RBPAE. vol. 21, n 1/2, jan./dez. 2005.

DOMINGUES, G. S; GUSSO, S. F. K. Estágio Supervisionado e formação de professores: "a integração necessária para a formação docente". Anais... Educere, 2005.

FÁVERO, A. A.; TONIETO, C. \& ROMAN, M. F. A formação de professores reflexivos: a docência como objeto de investigação. Revista do Centro de Educação, v. 38, n. 21, p. 277288, 2013.

FONTANA, M. J; FÁVERO, A. A. Professor reflexivo: uma interação entre teoria e prática. Revista de Educação do IDEAU, vol. 8, nº 17, jan/jun 2013.

GADOTTI, M. Boniteza de um sonho: ensinar-e-aprender com sentido. São Paulo. GRUBHAS, 2013.

GOES, C. R. O ser professor na contemporaneidade: entre a utopia de mudar o mundo e o desencantamento com a realidade. Trabalho de conclusão de curso: Universidade Federal do Rio Grande do Sul, Porto Alegre, 2014.

GOLDSCHIMIDT, A. I. Professores como cerrado: a cada chuva o esplendor da primavera. Amazônia: Revista de Educação em Ciências e Matemática. v.12 (24) Jan-Jul 2016. p. 26-38.

LIBÂNEO, J. C. Organização e gestão da escola: Teoria e prática. 6 ed. São Paulo: Editora Heccus, 2013.

MEDEIROS, M. A graça das coisas. Porto Alegre: L\&PM, 11 ed. 2013.

MOTA, E. A. D. O escrito e seu outro. In: PRADO, G. V. T; SOLIGO. R. (org.). Porque escrever é fazer história: revelações, subversões e superações. Campinas: Editora Alínea, 2007.

NÓVOA, A. Entrevista. Revista Pátio, v. VII, n 27, ago./out. 2003, p. 25-28.

PIMENTA, S. G.; LIMA, M. do S. L. L. O estágio e docência. São Paulo: Cortez, 2004.

PRADO, G. V. T; SOLIGO, R. Memorial de formação: quando as memórias narram a história da formação. In: PRADO, G. V. T; SOLIGO. R. (org.). Porque escrever é fazer história: revelações, subversões e superações. Campinas: Editora Alínea, 2007.

PROJETO POLÍTICO PEDAGÓGICO. Colégio Estadual Três Mártires. Palmeira das Missões/RS. 38 p. 2011.

RODRIGUES, P. A. M.. Anatomia e Fisiologia de um Estágio. Dissertação de Mestrado, PUCRio, 2009. 
RAMOS, T. et al. Constructos em narrativas do ser e do se fazer docente. Amazônia: Revista de Educação em Ciências e Matemática. v.13 (25) Jul-Dez 2016. p.46-61.

ROSA, M. C. C. A escrita dos professores: instrumento de reflexão sobre a prática pedagógica. In: PRADO, G. V. T; SOLIGO. R. (org.). Porque escrever é fazer história: revelações, subversões e superações. Campinas: Editora Alínea, 2007.

SANTANA, A. R. Olhar sobre tendências: o norte de minha práxis. Amazônia Revista de Educação em Ciências e Matemática, v.13 (25) Jul-Dez 2016. p.93-98.

SANTOS, V, J. O sonho de um jovem. São Paulo: Ed. Baraúna, 2010.

SANTOS, H. M. O estágio curricular na formação de professores: diversos olhares. In: $28^{a}$ REUNIÃO ANUAL DA ANPED, GT 8- Formação de Professores, 2005, Caxambu.

SCALABRIN, I. C.; MOLINARI, A. M. C. A importância da prática do estágio supervisionado nas licenciaturas. Revista Unar. Vol 7. n. 48 2013/3.

SILVA, K. S. Estágio e Escola-Campo - Protagonistas na construção de saberes dos alunos professores do curso de pedagogia do campus avançado de Catalão - UFG. Dissertação de Mestrado. São Paulo: Universidade de São Paulo, 2006.

SILVA, N. V.; GOLDSCHMIDT, A. I. Explorando ruas que quero ladrilhar: entre a paixão e o receio de ser professor. Revista Metáfora Educacional (ISSN 1809-2705) - versão on-line. Editora Dra. Valdeci dos Santos. Feira de Santana - Bahia (Brasil), n. 20 (jan. - jun. 2016), 25 jun. 2016, p. 134-161.

SOARES, M. Meta memórias-Memórias: travessia de uma educadora. São Paulo: Cortez, 2ed. 2001.

TARDIF, M. Saberes docentes e a formação profissional. Petrópolis: Vozes, 2012.

TARDIF, M; LESSARD, C. O trabalho docente: elementos para uma teoria da docência como profissão de interações humanas. Petrópolis: Vozes, 2009.

VEIGA, Ilma P. A. Projeto político-pedagógico da escola: uma construção coletiva. In: VEIGA, Ilma P. A. (org.). Projeto político-pedagógico da escola: uma construção possível. Campinas: Papirus, 2002.

WARSCHAUER, C. Rodas em rede: oportunidades formativas na escola e fora dela. Rio de Janeiro: Paz e Terra, 2001. 